ISSN 0258-7122

Bangladesh J. Agril. Res. 39(4): 641-659, December 2014

\title{
TUBER YIELD AND NUTRIENT BALANCE OF POTATO (Solanum tuberosum L.) CULTIVATION AS INFLUENCED BY DIFFERENT NUTRIENTS MANAGEMENT UNDER AEZ-28
}

\author{
M. A. H. S. JAHAN ${ }^{1}$, M. A. R. SARKAR ${ }^{2}$, N. C. D. BARMA ${ }^{3}$ \\ M. N. A. MONDAL ${ }^{4}$ AND M. N. S. FERDOUSI ${ }^{5}$
}

\begin{abstract}
A field experiment was conducted at Regional Wheat Research Centre of the Bangladesh Agricultural Research Institute, Joydebpur, Gazipur for 2 consecutive years during 2006-07 and 2007-08. The objectives were to find out the optimum nutrient management practice on tuber yield, nutrient balance and economics of potato cultivation. Twelve nutrient management treatments were tested in a randomized complete block design with 3 replications. Treatments were $\mathrm{T}_{1}=\mathrm{HYG}(0-198-44-194-24-6-1.2), \mathrm{T}_{2}=\mathrm{MYG}(0-140-34-138-18-4.5-0.9)$, $\mathrm{T}_{3}=$ IPNS (10000-168-38-170-18-6-1.2), $\mathrm{T}_{4}=\mathrm{STB}(0-171-40-164-22-5-1), \mathrm{T}_{5}=\mathrm{FP}$ (0-97-16-91-0-0-0), T $6=$ CON (0-0-0-0-0-0-0), T $7=$ HYG+CRI, T $8=\mathrm{MYG}+\mathrm{CRI}$, $\mathrm{T}_{9}=\mathrm{IPNS}+\mathrm{CRI}, \quad \mathrm{T}_{10}=\mathrm{STB}+\mathrm{CRI}, \quad \mathrm{T}_{11}=\mathrm{FP}+\mathrm{CRI}, \quad \mathrm{T}_{12}=\mathrm{CON}+\mathrm{CRI} \quad \mathrm{kg} \mathrm{ha}^{-1}$ CDNPKSZnB for potato. The highest tuber yield of potato was obtained from STB+CRI (27.64 $\left.\mathrm{t} \mathrm{ha}^{-1}\right)$ followed by IPNS+CRI (27.35 $\left.\mathrm{t} \mathrm{ha}^{-1}\right)$, STB (27.10 tha $\left.{ }^{1}\right)$, IPNS (26.83 $\left.\mathrm{t} \mathrm{ha}^{-1}\right), \mathrm{HYG}+\mathrm{CRI}\left(26.52 \mathrm{t} \mathrm{ha}^{-1}\right)$ and HYG $\left(26.10 \mathrm{t} \mathrm{ha}^{-1}\right)$ in 200607. Similar trend was found in 2007-08. The highest tuber yield and yield contributing parameters were noticed in CRI plots than without CRI. Except N, remaining nutrient balance like $\mathrm{P} K \mathrm{~K} \mathrm{Zn}$ and $\mathrm{B}$ were found positive in case of HYG, MYG, IPNS and STB along with or without CRI nutrient managements. The balance was found almost negative in case of FP and CON. The highest BCR was observed in STB+CRI (3.96) followed by STB (3.93), IPNS+CRI (3.76), and IPNS (3.74). The higher gross return (Tk. $283331 \mathrm{ha}^{-1}$ ) and also gross margin (Tk. $211761 \mathrm{ha}^{-1}$ ) was observed from the same treatment.
\end{abstract}

Keywords: Potato, Tuber yield, Nutrient balance, Economics and Crop Residue Incorporation.

\section{Introduction}

Bangladesh is a small country of 0.148 million sq.km with a population of 145 million (BBS, 2011). In order to produce more food within a limited area, it is important to increase the productive efficiency of the individual crop depending on how well it utilizes the basic resources especially, the limiting ones, like water and nutrients. Potato is an important food crop in Bangladesh. It ranks third after rice and wheat. It gives more financial return from unit area and unit time

${ }^{1}$ Principal Scientific Officer, RWRC, ${ }^{3}$ Chief Scientific Officer, RWRC, ${ }^{4}$ Chief Scientific Officer, RARS, Bangladesh Agricultural Research Institute (BARI), Gazipur, ${ }^{2}$ Prof. Dept. of Agronomy, Bangladesh Agricultural University (BAU), Mymansingh, ${ }^{5}$ PBI, Dhaka, Bangladesh. 
compared to rice and wheat. Potato is a high yield potential tuber crop and its potential yield is estimated at 25-30 $\mathrm{tha}^{-1}$ in Bangladesh (Satter et al., 2005). It is 5-6 times higher than rice and 8-10 times higher than wheat yield. It may appear as a good substitute of rice and wheat. Potato is a good source of energy and contains high levels of minerals and proteins. It provides over twice as much dry matter and calories unit ${ }^{-1}$ area of land and time, as compared to rice or wheat (Couto et al., 1983). Potato protein has limited sulphur containing amino acids, but contains substantially more lysine compared to cereals and is thus a good food supplement (Woolf, 1987). It was revealed that a positive effect of application of nutrients from organic and inorganic sources and their combinations on tuber yield of potato (Biswas, 2011). Therefore, the present study was undertaken with the following objectives to find out the optimum nutrient management practice for tuber yield, apparent nutrient balance in soil and economics of potato cultivation under AEZ-28.

\section{Materials and method}

The experiment was carried out at the Regional Wheat Research Centre of Bangladesh Agricultural Research Institute Joydebpur, Gazipur. The experimental field belongs to the agro-ecological zone of Modhupur Tract (AEZ28). The initial soil status was $\mathrm{pH} 6.48$, OM (\%) 1.07, Total $\mathrm{N}(\%) 0.055$, available $\mathrm{P}\left(\mu \mathrm{g} \mathrm{g}^{-1}\right) 3.76$, exchangable $\mathrm{K}$ (meq $\left.100 \mathrm{~g}^{-1}\right) 0.15$, available $\mathrm{S}\left(\mu \mathrm{g} \mathrm{g} \mathrm{g}^{-1}\right)$ 9.91, available $\mathrm{Zn}\left(\mu \mathrm{g} \mathrm{g}^{-1}\right) 0.24$ and available $\mathrm{B}\left(\mu \mathrm{g} \mathrm{g}{ }^{-1}\right) 0.16$. Morphological characters are Grey Terrace soils, medium high land, not well drained, above flood level and grey soil clour. Soil texture was silty loam to loam with very low to low soil fertility. Potato (BARI-Alu 8, Cardinal variety) was tested in Rabi season during 2006-07 and 2007-08. Twelve nutrient management treatments were tested in a randomized complete block design with 3 replications. Treatments were $\mathrm{T}_{1}=\mathrm{HYG}(0-198-44-194-24-6-1.2), \mathrm{T}_{2}=\mathrm{MYG}(0-140-34-138-$ 18-4.5-0.9), $\mathrm{T}_{3}=$ IPNS (10000-168-38-170-18-6-1.2), $\mathrm{T}_{4}=\mathrm{STB}(0-171-40-164-22-$ $5-1), \quad \mathrm{T}_{5}=\mathrm{FP} \quad(0-97-16-91-0-0-0), \quad \mathrm{T}_{6}=\mathrm{CON} \quad(0-0-0-0-0-0-0), \quad \mathrm{T}_{7}=\mathrm{HYG}+\mathrm{CRI}$, $\mathrm{T}_{8}=\mathrm{MYG}+\mathrm{CRI}, \mathrm{T}_{9}=\mathrm{IPNS}+\mathrm{CRI}, \mathrm{T}_{10}=\mathrm{STB}+\mathrm{CRI}, \mathrm{T}_{11}=\mathrm{FP}+\mathrm{CRI}, \mathrm{T}_{12}=\mathrm{CON}+\mathrm{CRI} \mathrm{kg}$ ha $^{-1}$ CDNPKSZnB, Here HYG $=$ High Yield Goal, MYG= Moderate Yield Goal, IPNS $=$ Integrated Nutrient Management System, STB $=$ Soil Test Based, FP= Farmers' Practice, $\mathrm{CON}=$ Control, $\mathrm{CD}=$ Cowdung and $\mathrm{CRI}=$ Crop Residue Incorporated. The previous crop was T. Aman rice and one-third residue of T. Aman rice was incorporated before potato planting. The rates for $\mathrm{N}, \mathrm{P}, \mathrm{K}, \mathrm{S}, \mathrm{Zn}$ and $\mathrm{B}$ were calculated based on the soil test value following the soil test interpretation (BARC, 2005). The rate for each element was considered as $100 \%$. Accordingly, the full or $100 \%$ rate of N, P, K, S, Zn and B for each crop was applied. In case of Integrated Plant Nutrient System (IPNS) treatment the amount of nutrients available in cowdung (CD) was deducted from the total amount of chemical fertilizers and adjusted accordingly. The rates for chemical fertilizers 
were fixed on soil test basis (STB) with a high yield goal (HYG) for specific crop basis (BARC, 2005). The exact fertilizer nutrient for making the recommendation was computed with the following formula:

$$
\mathrm{F}_{\mathrm{r}}=\mathrm{U}_{\mathrm{f}}-\frac{\mathrm{C}_{\mathrm{i}}}{\mathrm{C}_{\mathrm{s}}} \times\left(\mathrm{S}_{\mathrm{t}}-\mathrm{L}_{\mathrm{s}}\right)
$$

Where

$\mathrm{F}_{\mathrm{r}}=$ Fertilizer nutrient required for a given soil test value

$\mathrm{U}_{\mathrm{f}}=$ Upper limit of the recommended fertilizer nutrient for the respective soil test value interpretation (STVI) class

$\mathrm{C}_{\mathrm{i}}=$ Units of class intervals used for fertilizer nutrient recommendation

$\mathrm{C}_{\mathrm{s}}=$ Units of class intervals used for STVI class

$\mathrm{S}_{\mathrm{t}}=$ Soil test value

$\mathrm{L}_{\mathrm{s}}=$ Lower limit of the soil test value within STVI class.

For HYG, MYG and IPNS management recommended cowdung was adjusted into chemical nutrient and added according to the thumb rule i.e. 1 ton decomposed cowdung contains $3 \mathrm{~kg} \mathrm{~N}, 0.6 \mathrm{~kg} \mathrm{P}, 2.4 \mathrm{~kg} \mathrm{~K}$ and $0.6 \mathrm{~kg} \mathrm{~S}$ (BARC, 2005). The sources of N, P, K, S, Zn and B were urea, triple super phosphate (TSP), muriate of potash (MoP), gypsum, zinc sulphate and boric acid, respectively. The farmers' practice (FP) for fertilizer rates was determined on the basis of data collected through interviewing thirty (30) farmers from adjacent locality. It appeared that the farmers generally did not use S, Zn and B fertilizers. Residue of previous crop was in-situ incorporated to the soil for crop residue incorporation plots. The amount of crop residue was varied from 0.52 to $2.22 \mathrm{t}$ $\mathrm{ha}^{-1} \mathrm{yr}^{-1}$ (dry basis) depend on irrespective treatment. Actually, remaining onethird (height basis) of the total straw was cut and that was incorporated. Total remaining residue was chopped just after harvest and ploughed down to the soil by spade for decomposition in respective CRI plots. Potato whole seeds were planted in November 26-30 each year with a seed rate of 1.5 ton $\mathrm{ha}^{-1}$. Spacing was $60 \mathrm{~cm}$ x $25 \mathrm{~cm}$. Seeds were covered with soil just after planting. One-half of urea and the whole amount of TSP, MoP, gypsum, zinc sulphate and boric acid were applied at the time of final land preparation as per treatment. Remaining one-half of urea was applied at 30 days after planting. Weeding was done twice at 15 and 30 days after planting of potato. Three irrigations were applied at just after planting, 30 and 60 days of planting. Plant protection measures were followed as and when necessary. The crops were harvested at full maturity. Potato was harvested on 25-28 February each year. An area of $8.1 \mathrm{~m}^{2}$ each plot were harvested to record tuber and foliage yields. A sub-sample of $200 \mathrm{~g}$ dry biomass (foliage and tuber) for each of the crop was collected for chemical 
(nutrient uptake) analysis. The data on the yield contributing characters were recorded from 10 randomly selected hills for potato. Total fresh foliage yield was measured from the harvested area. Then a sub-sample from each plot was collected and weighed to record fresh weight. The sub-samples were dried in an oven for 72 hours at $70^{\circ} \mathrm{C}$. Oven dry of each sample was recorded and expressed as dry foliage yield $\left(\mathrm{t} \mathrm{ha}^{-1}\right)$. Apparent nutrient balance (added-uptake) was calculated using the following formula.

$X_{a}=\left(X_{f}+X_{r}+X_{i}+X_{b}+X_{\text {cri }}\right)-X_{\text {rem }}$

Where

$\mathrm{Xa}=$ Apparent gain $(+)$ or loss (-) of nutrient $\left(\mathrm{kg} \mathrm{ha}^{-1}\right)$

$\mathrm{Xf}=$ Nutrient added through inorganic sources $\left(\mathrm{kg} \mathrm{ha}^{-1}\right)$

$\mathrm{Xr}=$ Nutrient added through rainfall $\left(\mathrm{kg} \mathrm{ha}^{-1}\right)$. (Not considered $)$

$\mathrm{Xi}=$ Nutrient added through irrigation water $\left(\mathrm{kg} \mathrm{ha}^{-1}\right) .($ Not considered $)$

$\mathrm{Xb}=$ Nutrient added through BNF $\left(\mathrm{kg} \mathrm{ha}^{-1}\right)$. (Not considered)

$\mathrm{Xcri}=$ Nutrient added through crop residue incorporation $\left(\mathrm{kg} \mathrm{ha}^{-1}\right)$.

Xrem $=$ Nutrient removed by crops and loss through different systems $\left(\mathrm{kg} \mathrm{ha}^{-1}\right)$.

The mean comparisons of the treatments were evaluated by DMRT (Duncan's Multiple Range Test).

\section{Results and discussion}

\section{Number of hills $\mathbf{m}^{-2}$}

The number of hills $\mathrm{m}^{-2}$ did not vary significantly due to nutrient management treatments in both the years (Table 1).

\section{Plant height}

The nutrient management treatments without or with crop residues incorporation influenced the plant height significantly in both years. The maximum plant height was recorded under HYG with CRI $(64.9 \mathrm{~cm})$ which was similar to HYG $(64.8$ $\mathrm{cm})$, IPNS+CRI $(63.9 \mathrm{~cm})$, STB+CRI $(61.9 \mathrm{~cm})$, STB $(61.4 \mathrm{~cm})$ and IPNS $(60.8$ $\mathrm{cm})$. The plant height under the control without CRI was $27.6 \mathrm{~cm}$ and with CRI was $28.2 \mathrm{~cm}$ in Table 1 .

From Table 1, it observed that the plant height was the highest in HYG followed by IPNS and STB without or with CRI treatments. These results might be due addition of higher amount of nitrogen which enhanced the plant height as well as vegetative growth. The treatment MYG and FP gave comparatively short plant that might be due to irrespective nutrient management treatments. The lowest plant height was in control due to poor nutrient effect. However, the plant 
height increased in all the treatments with crop residues incorporation than without incorporation. Crop residues incorporation added some extra nutrients to the soil, which probably affected plant height positively. Hossain et al. (2008) also obtained the maximum plant height in T. Aman rice when used STB nutrient $\mathrm{N}_{147} \mathrm{P}_{32} \mathrm{~K}_{54} \mathrm{~S}_{18} \mathrm{Zn}_{4} \mathrm{~B}_{1.02} \mathrm{ka} \mathrm{ha}^{-1}$ nutrient in potato-T. Aman rice cropping pattern. However, the crop residue was not incorporated.

\section{Number of stems $\mathbf{m}^{-2}$}

The nutrient management packages had positive impact on the number of stems $\mathrm{m}^{-2}$ in 2006-07 and 2007-08. The nutrient management treatments HYG, IPNS and STB without or with crop residues incorporation produced statistically identical number of stems $\mathrm{m}^{-2}$ in Table 1. The STB+CRI treatment had the maximum (33.22) stems $\mathrm{m}^{-2}$, while the control had 17.60 and 18.40 stems $\mathrm{m}^{-2}$ without or with CRI, respectively. The number of stems $\mathrm{m}^{-2}$ increased slightly due to addition of crop residues in soil.

It was observed that the HYG, MYG, IPNS, STB and FP without or with CRI treatments produced the maximum number of stems $\mathrm{m}^{-2}$ in both the years. The trend of production of stems $\mathrm{m}^{-2}$ was similar, which might be due to using about $40 \mathrm{~mm}$ to $55 \mathrm{~mm}$ sized tubers in the experiment containing about 4-6 eyes per tuber. As a result, number of stems $\mathrm{m}^{-2}$ was not affected by different nutrient management treatments. The number of stems $\mathrm{m}^{-2}$ was higher with CRI than without CRI in all the treatments that might be due to crop residual effect. Overall impact of different nutrient management treatments on number of stems $\mathrm{m}^{-2}$ was not so pronounced though the nutrient variations were remarkable. Similar results were reported by Sarkar et al. (1996). They obtained the maximum stems $\mathrm{m}^{-2}$ when STB nutrients i.e. $\mathrm{N}_{150} \mathrm{P}_{2} \mathrm{O}_{5}{ }_{60} \mathrm{~K}_{2} \mathrm{O}_{120} \mathrm{~S}_{20} \mathrm{Zn}_{4} \mathrm{~B}_{2}$ $\mathrm{Mg}{ }_{15} \mathrm{Mn}{ }_{0} \mathrm{CD}{ }_{0} \mathrm{~kg} \mathrm{ha}^{-1}$ were applied. Those authors did not use the crop residues in their studies but in the present study crop residues were incorporated.

\section{Number of tubers hill ${ }^{-1}$}

Number of tubers hill ${ }^{-1}$ under the nutrient management treatments without CRI was statistically identical to the treatments with CRI in both years. The maximum number of tubers hill ${ }^{-1}$ was (10.81) obtained with STB+CRI treatment, which was statistically identical to a number of nutrient management treatments like STB (10.78), IPNS+CRI (10.70), IPNS (10.67), HYG+CRI (10.51) and HYG (10.47). Except the FP and control treatments, the MYG treatment with or without CRI showed statistically identical number of tubers hill ${ }^{-1}$. The control with or without CRI produced the lowest number of tubers hill ${ }^{-1}$ in Table 1.

From the two years results, it was found that the maximum number of tubers hill $^{-1}$ was produced by the HYG, IPNS and STB without or with CRI treatments 
compared to the control. Among those treatments, STB performed better followed by IPNS and HYG. The MYG treatment and FP gave moderate and low number of tubers hill ${ }^{-1}$ that might be due to moderate and low nutrient added in to the soil. Control treatments gave the lowest number of tubers hill ${ }^{-1}$, which was due to poor nutrient status of the soil. However, the number of tubers hill ${ }^{-1}$ was found to be higher with CRI than without CRI. Crop residues integration added some extra nutrient to soil which might have increased the number of tubers hill ${ }^{-1}$ (Table 3). These results are in agreement with that of Ali et al. (2009). They recorded the highest number of tubers hill ${ }^{-1}$ when nutrient was applied @ $\mathrm{N}_{132} \mathrm{P}_{27}$ $\mathrm{K}_{105} \mathrm{~S}_{19} \mathrm{Zn}_{4} \mathrm{CD}_{5000} \mathrm{~kg} \mathrm{ha}^{-1}$ in potato-Boro rice -T. Aman rice cropping pattern. Moreover, the above authors did not use crop residues in their studies while crop residues were used in the present study. Similar results were also reported by some other researchers (Sarkar et al., 1996; Khan et al., 2005; Chowdhury et al., 2007).

\section{Tuber weight hill ${ }^{-1}$}

The mean tuber weight hill ${ }^{-1}$ has been presented in Table 2. Nutrient management treatments without or with CRI showed highly significant differences for tuber weight hill $^{-1}$. Among the treatments, STB+CRI gave the highest tuber weight hill ${ }^{1}$ (533 g), which was identical to STB (531 g), IPNS+CRI (528 g), IPNS (526 g), HYG+CRI (517 g) and HYG (515 g). The control without CRI showed the lowest tuber weight $(117 \mathrm{~g})$.

The nutrient management treatments like HYG, IPNS and STB with or without crop residues incorporation gave the maximum tuber weight hill $^{-1}$. Among those treatments, the highest tuber weight hill ${ }^{-1}$ was under STB followed by IPNS and HYG. These results might be due to the influence of nutrients applied as required. While the treatment MYG and FP gave moderate and low tuber weight hill ${ }^{-1}$ that might be due to the effect of moderate and low nutrient treatments applied into the soil. The control treatment gave the lowest tuber weight hill $^{-1}$. However, the heavier tuber weight hill ${ }^{-1}$ was found with CRI than without CRI that might be due to addition of some extra nutrient from the crop residues incorporation (Table 3). The trend of tuber weight hill ${ }^{-1}$ was almost similar over the years. These results are in agreement with that Hossain et al. (2008). They stated that maximum tuber weight hill $^{-1}$ was obtained by using STB nutrient $\mathrm{N}_{147} \mathrm{P}_{32} \mathrm{~K}_{54} \mathrm{~S}_{18} \mathrm{Zn}_{4} \mathrm{~B}_{1.02} \mathrm{~kg} \mathrm{ha}^{-1}$ fertilizer in potato-fallow-T. Aman rice cropping pattern and Ali et al. (2009) recorded the highest number of tuber weight hill ${ }^{-1}$ when nutrient was applied @ $\mathrm{N}_{132} \mathrm{P}_{27} \mathrm{~K}_{105} \mathrm{~S}_{19} \mathrm{Zn}_{4} \mathrm{CD}_{5000} \mathrm{~kg} \mathrm{ha}^{-1}$ in potato-Boro rice -T. Aman rice cropping pattern. Moreover, crop residues were used in the present study while the previous authors did not. These results are in conformity with some other authors (Khan et al., 2005). 


\section{Tuber yield}

Most of the nutrient management treatments except farmers' practice (FP) and control without or with CRI were statistically identical for tuber yield in both years in Table 2. The treatment STB+CRI gave the highest tuber yield (28.31t ha ${ }^{1}$ ). On the other hand, MYG treatment without or with CRI produced moderate tuber yield 22.98 and $23.10 \mathrm{t} \mathrm{ha}^{-1}$, respectively. The control without CRI produced the lowest yield $\left(6.10 \mathrm{tha}^{-1}\right)$.

It revealed that the nutrient management treatments like HYG, IPNS and STB without or with crop residues incorporation gave the highest tuber yield. Among them, STB was the best over the years followed by IPNS and HYG. These results might be due to the combined effect of higher number of tubers hill ${ }^{1}$ and tuber weight hill ${ }^{-1}$. Those yields were statistically identical. On the other hand, the treatments MYG and FP without or with CRI gave moderate and average tuber yield that might be due to the effect of respective number of tubers hill $^{-1}$ and tuber weight hill ${ }^{-1}$. The control treatment gave the lowest tuber yield due to the minimum number of tubers hill ${ }^{-1}$ and tuber weight hill ${ }^{-1}$. Anyway, the tuber yield was higher with CRI than without CRI might be due to the effect of higher yield contributing parameters like number of tubers hill ${ }^{-1}$ and tuber weight hill $^{-1}$. Moreover, addition of extra nutrient from crop residues incorporation positively influenced these parameters (Table 3). Overall, the trend of tuber yield was more or less similar in both the years might be due to the same amount of nutrient were applied in both the years. These results were similar to that of Hossain et al. (2008) who recorded the highest tuber yield by using $\mathrm{N}_{147} \mathrm{P}_{32} \mathrm{~K}$ ${ }_{54} \mathrm{~S}_{18} \mathrm{Zn}_{4} \mathrm{~B}_{1.02} \mathrm{ka} \mathrm{ha}^{-1}$ fertilizer in potato-fallow-T. Aman rice cropping pattern. Those authors did not use crop residues as treatment in their studies. Similar results were also stated by some other researchers (Sarkar et al., 1996; Khan et al., 2005).

\section{Dry foliage yield}

The maximum dry foliage yield was $2.31 \mathrm{t} \mathrm{ha}^{-1}$ under HYG with crop residue incorporation, which was statistically identical to IPNS+CRI $\left(2.21 \mathrm{t} \mathrm{ha}^{-1}\right), \mathrm{HYG}$ $\left(2.19 \mathrm{t} \mathrm{ha}^{-1}\right)$, IPNS $\left(2.14 \mathrm{tha}^{-1}\right)$, STB+CRI $\left(2.11 \mathrm{t} \mathrm{ha}^{-1}\right)$ and STB $\left(2.07 \mathrm{tha}^{-1}\right)$. The treatment MYG without or with CRI gave moderate dry foliage yield, having 1.87 and $1.90 \mathrm{t} \mathrm{ha}^{-1}$, respectively. The control without CRI had $0.37 \mathrm{t} \mathrm{ha}^{-1}$ and with CRI $0.42 \mathrm{t} \mathrm{ha}^{-1}$ in Table 2.

The nutrient management treatments like HYG without or with CRI produced the maximum dry foliage yield followed by IPNS and STB without or with CRI (Table 2). These findings were probably attributed to respective plant height as well as dry foliage yield. On the other hand, MYG and FP without or with CRI gave moderate and low dry foliage yield which might be due to its 
lower plant height and foliage weight. The control treatment produced the minimum foliage yield due to the lowest plant height and foliage weight. Among the treatments, the trend of foliage yield was higher with CRI than without CRI might be due to crop residual effect of T. Aman rice in both the years (Table 3). The trend was almost similar in both the years that might be due to the effect of same treatment. Similar results were reported by Hossain et al. (2008). They recorded the highest tuber yield when used $\mathrm{N}_{147} \mathrm{P}_{32} \mathrm{~K}_{54} \mathrm{~S}_{18} \mathrm{Zn}_{4} \mathrm{~B}_{1.02} \mathrm{ka} \mathrm{ha}^{-1}$ fertilizer without crop residue incorporation in potato-fallow-T. Aman rice cropping pattern.

\section{Apparent nutrient uptake and balance}

Total nutrient uptake (Tuber+ Foliage) of N P K S Zn and B was significantly influenced by different nutrient management treatments in 2006-07 and 2007-08 for potato (statistically analyzed but not shown here) and balance (two years mean) (not statistically analyzed) was calculated normally and discussed below (Fig. 1-6).

\section{Nitrogen}

From the mean data it was observed that the added of nutrient ranged from 0 to $81 \mathrm{~kg} \mathrm{ha}^{-1} \mathrm{yr}^{-1}$ (40\% of applied chemical/cowdung/crop residues nutrient $\mathrm{N}$ was considered effective) while uptake ranged from 28 to $143 \mathrm{~kg} \mathrm{ha}^{-1} \mathrm{yr}^{-1}$ among different treatments (Fig.1). Maximum uptake was found in STB+CRI (143 kg $\left.\mathrm{ha}^{-1} \mathrm{yr}^{-1}\right)$ followed by IPNS+CRI $\left(142 \mathrm{~kg} \mathrm{ha}^{-1} \mathrm{yr}^{-1}\right)$. Minimum uptake was estimated in both CON and CON+CRI $\left(28 \mathrm{~kg} \mathrm{ha}^{-1} \mathrm{yr}^{-1}\right)$. The apparent nutrient balance was found negative in all treatments ranging from -28 to $-73 \mathrm{~kg} \mathrm{ha}^{-1} \mathrm{yr}^{-1}$. The highest negative balance was found in IPNS+CRI $\left(-73 \mathrm{~kg} \mathrm{ha}^{-1} \mathrm{yr}^{-1}\right)$ followed by STB+CRI and STB $\left(-72 \mathrm{~kg} \mathrm{ha}^{-1} \mathrm{yr}^{-1}\right)$. The lowest negative balance was observed in both CON and CON+CRI $\left(-28 \mathrm{~kg} \mathrm{ha}^{-1} \mathrm{yr}^{-1}\right)$.

Fig. 1, shows that the nitrogen balance was negative as the uptake was higher compared to added nitrogen (40\% of applied chemical/cowdung/crop residues nutrient $\mathrm{N}$ was considered effective). Generally the nutrient uptake was governed by the total dry matter content of biological yield (Tuber+Foliage) and the concentration of respective nutrient element. The nutrient uptake depends on the type of treatments as well. Nitrogen replenishment through chemical fertilizer, cowdung addition, crop residue incorporation either singly or in combination was not enough to balance $\mathrm{N}$ removal by crop; so much of the applied $\mathrm{N}$ was lost from the soil through depletion. The $\mathrm{N}$ balance thus was negative in all treatments appeared to have been removed in excess of the quantity added in soil. However, the $\mathrm{N}$ balance was less negative in those treatments where crop residues were incorporated than without incorporation which might be due to addition of extra $\mathrm{N}$ from crop residues 2 to $5 \mathrm{~kg} \mathrm{ha}^{-1} \mathrm{yr}^{-1}$ (Table 3). Present findings are also in agreement with some other researchers (Timsina et al., 2001 and 2006). 
TUBER YIELD AND NUTRIENT BALANCE OF POTATO

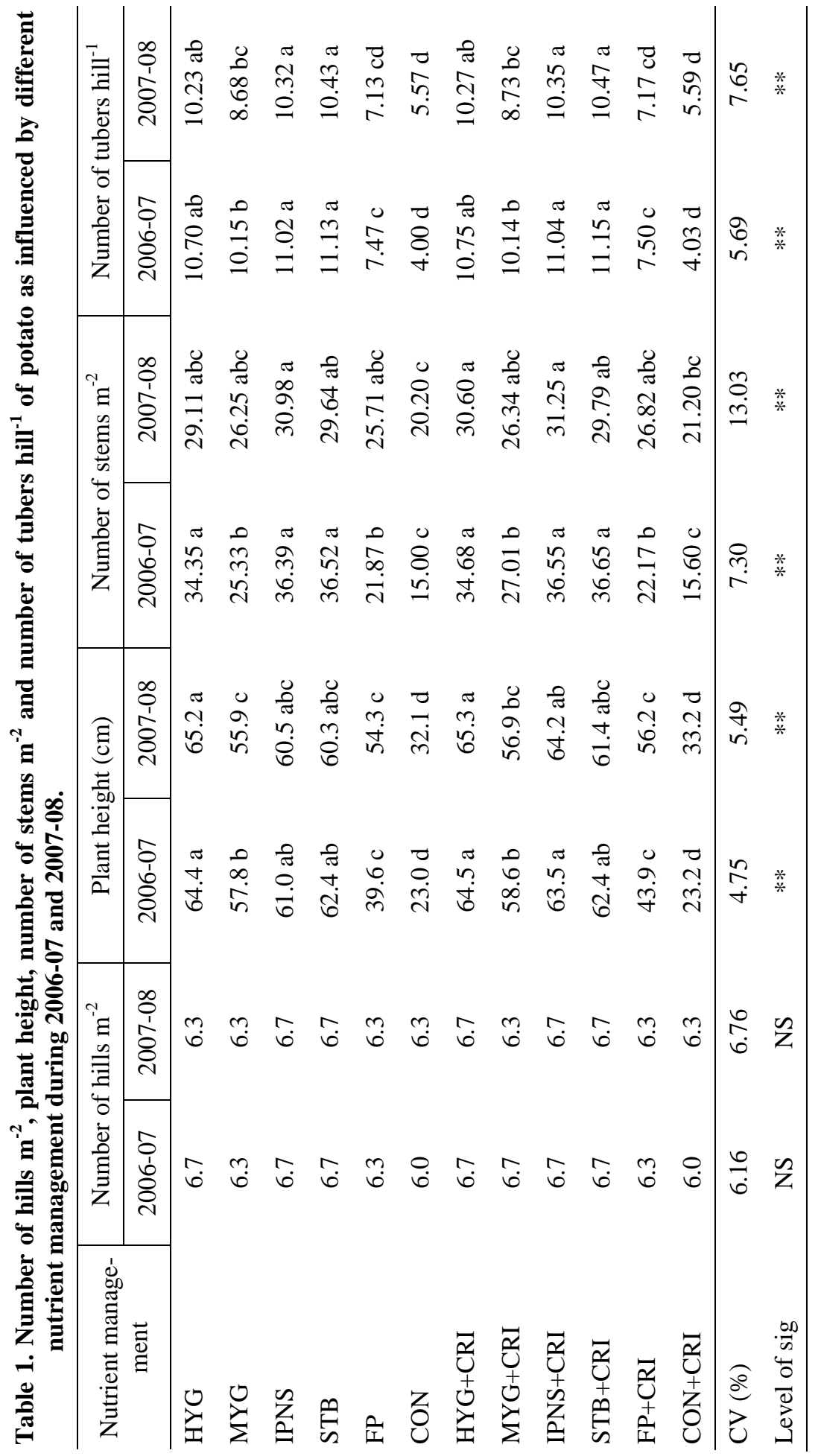




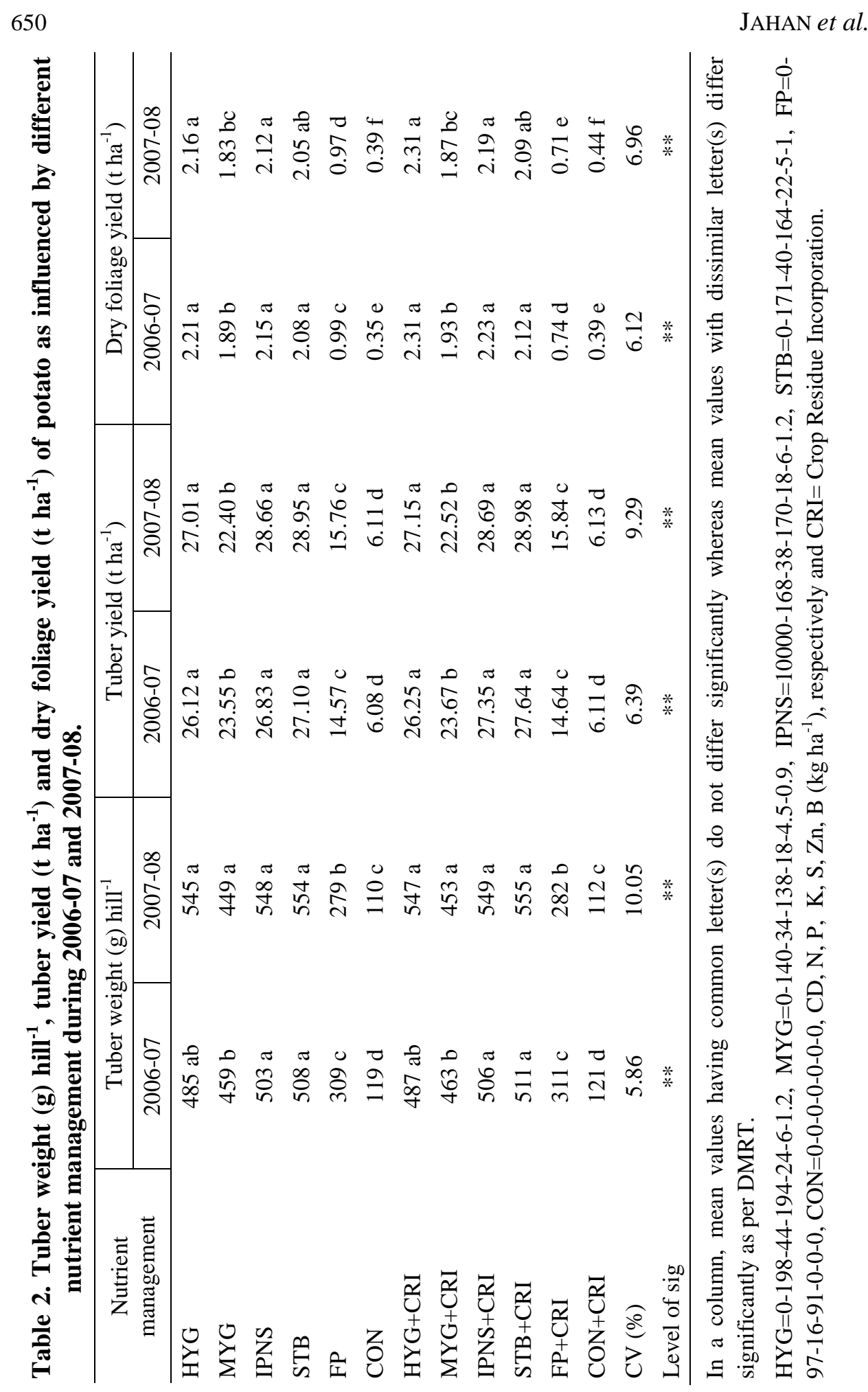




\section{Phosphorus}

The added phosphorus was in the range from 0 to $46 \mathrm{~kg} \mathrm{ha}^{-1} \mathrm{yr}^{-1}$ in respective of different treatments. The uptake was ranged from 5 to $31 \mathrm{~kg} \mathrm{ha}^{-1} \mathrm{yr}^{-1}$. The treatments STB and IPNS+CRI showed the highest and similar uptake (31 kg ha $\left.{ }^{1} \mathrm{yr}^{-1}\right)$ followed by IPNS (29 $\left.\mathrm{kg} \mathrm{ha}^{-1} \mathrm{yr}^{-1}\right)$. The lowest uptake was found in CON and CON+CRI $\left(5 \mathrm{~kg} \mathrm{ha}^{-1} \mathrm{yr}^{-1}\right)$. The negative balance was found in control $(-5 \mathrm{~kg}$ $\left.\mathrm{ha}^{-1} \mathrm{yr}^{-1}\right)$ and FP $\left(-1 \mathrm{~kg} \mathrm{ha}^{-1} \mathrm{yr}^{-1}\right)$ nutrient management treatments from mean data shown in Fig. 2. On the other hand, remaining treatments showed positive balance in the range of 9-22 $\mathrm{kg} \mathrm{ha}^{-1} \mathrm{yr}^{-1}$. Maximum positive balance was found in $\mathrm{HYG}+\mathrm{CRI}\left(22 \mathrm{~kg} \mathrm{ha}^{-1} \mathrm{yr}^{-1}\right)$ followed by HYG $\left(20 \mathrm{~kg} \mathrm{ha}^{-1} \mathrm{yr}^{-1}\right)$. Minimum positive balance was noticed in IPNS and STB $\left(9 \mathrm{~kg} \mathrm{ha}^{-1} \mathrm{yr}^{-1}\right)$.

From the figure 2, it was observed that the HYG, MYG, IPNS and STB without or with crop residue incorporation treatments showed positive balance due to addition of higher amount of phosphorus nutrient with lower nutrient uptake that might be due to total dry matter content as well as the variation of concentration of the nutrient of the crops. In FP and control treatments the balance appeared negative due to addition of inadequate and no nutrient into the soil whereas uptake was higher. The positive balance was higher in those treatments where the crop residue were incorporated with soil than without incorporated treatments which might be due to addition of extra nutrient in the range of 1-2 $\mathrm{kg} \mathrm{ha}^{-1} \mathrm{yr}^{-1}$ (Table 3). Similar results were also found by Saleque et al., 2006).

\section{Potassium}

The quantity of added nutrient $(\mathrm{K})$ was in the range of 0 to $205 \mathrm{~kg} \mathrm{ha}^{-1} \mathrm{yr}^{-1}$ and uptake by the crop varied from 33 to $169 \mathrm{~kg} \mathrm{ha}^{-1} \mathrm{yr}^{-1}$. Maximum uptake was found in HYG+CRI (169 kg ha $\left.{ }^{-1} \mathrm{yr}^{-1}\right)$ followed by HYG (168 kg ha $\left.\mathrm{yr}^{-1}\right)$. Minimum uptake was observed in CON and CON+CRI (33 $\left.\mathrm{kg} \mathrm{ha}^{-1} \mathrm{yr}^{-1}\right)$. Among the nutrient management treatments, only control showed negative balance in the range of -28 to $-33 \mathrm{~kg} \mathrm{ha}^{-1} \mathrm{yr}^{-1}$. Rest of the treatments showed positive balance ranged from 8 to 36 $\mathrm{kg} \mathrm{ha}^{-1} \mathrm{yr}^{-1}$. Maximum positive balance was observed in HYG+CRI $\left(36 \mathrm{~kg} \mathrm{ha}^{-1} \mathrm{yr}^{-1}\right)$ and minimum was found in both STB and FP $\left(8 \mathrm{~kg} \mathrm{ha}^{-1} \mathrm{yr}^{-1}\right)$ as shown in Fig. 3.

It is revealed that the balance was found comparatively a little bit positive in a number of treatments that might be due to less uptake of nutrient than the quantity added. That possibly happened by the influence of total dry matter production and variation in nutrient concentration in those respective treatments in both the years. However, the positive balance was relatively higher in crop residues incorporated plots than non incorporated plots in both the years. It might happen due to addition of extra nutrient in the range of 5 to $11 \mathrm{~kg} \mathrm{ha}^{-1} \mathrm{yr}^{-1}$ through crop residues incorporation (Table 3). This result is in agreement with Panaullah et al. (2006). 


\section{Sulphur}

It was observed that quantity of added $\mathrm{S}$ ranged from 0 to $26 \mathrm{~kg} \mathrm{ha}^{-1} \mathrm{yr}^{-1}$ and the uptake ranged from 2 to $13 \mathrm{~kg} \mathrm{ha}^{-1} \mathrm{yr}^{-1}$ with irrespective treatments. Among the treatments, maximum $\mathrm{S}$ uptake was observed in IPNS+CRI (13 kg ha $\left.\mathrm{yr}^{-1}\right)$ followed by HYG, IPNS, STB, STB+CRI $\left(11 \mathrm{~kg} \mathrm{ha}^{-1} \mathrm{yr}^{-1}\right)$. Minimum uptake was found in CON and CON+CRI $\left(2 \mathrm{~kg} \mathrm{ha}^{-1} \mathrm{yr}^{-1}\right)$. The negative balance as observed in $\mathrm{FP}$ and control treatments, which was -1 to $-6 \mathrm{~kg} \mathrm{ha}^{-1} \mathrm{yr}^{-1}$. Remaining treatments showed positive balance ranging from 7 to $16 \mathrm{~kg} \mathrm{ha}^{-1} \mathrm{yr}^{-1}$ (Fig. 4). Among the treatments, the maximum positive balance was observed in HYG+CRI (16 kg ha $\left.{ }^{1} \mathrm{yr}^{-1}\right)$ that was followed by HYG $\left(13 \mathrm{~kg} \mathrm{ha}^{-1} \mathrm{yr}^{-1}\right)$. The minimum positive balance was found in IPNS and IPNS+CRI MYG $\left(7 \mathrm{~kg} \mathrm{ha}^{-1} \mathrm{yr}^{-1}\right)$.

It was observed that only two treatments such as FP and control showed negative balance (two years mean) due to addition of low or no $S$ in the soil and as uptake was high which might be due to total dry matter accumulation and variation of nutrient concentration of respective treatments. Rest of the treatments showed positive balance that might be due to addition of high amount of nutrient. However, from the mean data it was noticed that the positive balance was higher in those treatments where crop residues were incorporated than without incorporation. Possibly it was due to addition of extra nutrient from crop residues in the range of 1 to $2 \mathrm{~kg} \mathrm{ha}^{-1} \mathrm{yr}^{-1}$ (Table 3). These results are in agreement with Khan et al. (2005).

\section{Zinc}

The amount of nutrient $(\mathrm{Zn})$ added in different nutrient treatment was in the range of 0 to $6 \mathrm{~kg} \mathrm{ha}^{-1}$ and uptake was in the range 0.07 to $0.40 \mathrm{~kg} \mathrm{ha}^{-1} \mathrm{yr}^{-1}$ with different treatments (Fig 5). Maximum uptake was observed in IPNS+CRI (0.40 $\left.\mathrm{kg} \mathrm{ha}^{-1} \mathrm{yr}^{-1}\right)$ that was followed by STB+CRI $\left(0.38 \mathrm{~kg} \mathrm{ha}^{-1} \mathrm{yr}^{-1}\right)$. Minimum uptake was found in CON and CON+CRI $\left(0.07 \mathrm{~kg} \mathrm{ha}^{-1} \mathrm{yr}^{-1}\right)$. The highest negative balance was noticed in FP $\left(-0.18 \mathrm{~kg} \mathrm{ha}^{-1} \mathrm{yr}^{-1}\right)$ and the lowest in CON and $\mathrm{CON}+\mathrm{CRI}\left(-0.07 \mathrm{~kg} \mathrm{ha}^{-1} \mathrm{yr}^{-1}\right)$. Other treatments showed positive balance ranged from 4.18 to $5.69 \mathrm{~kg} \mathrm{ha}^{-1} \mathrm{yr}^{-1}$. Among the treatments, maximum positive balance was noticed in $\mathrm{HYG}+\mathrm{CRI}\left(5.69 \mathrm{~kg} \mathrm{ha}^{-1} \mathrm{yr}^{-1}\right)$ which was followed by HYG (5.66 $\left.\mathrm{kg} \mathrm{ha}^{-1} \mathrm{yr}^{-1}\right)$. Minimum positive balance was observed in MYG $\left(4.18 \mathrm{~kg} \mathrm{ha}^{-1} \mathrm{yr}^{-1}\right)$.

From the mean data of two years, it was noticed that farmers' practice and control treatments showed negative balance of zinc. Because there was poor and no nutrient (native nutrient only) was added into the soil whereas a considerable amount of nutrient was removed by the crops through total dry matter production as well as respective nutrient concentration variation resulting the balance became negative. On the other hand, rest of the treatments had positive balance. 
Because, the amount of nutrient uptake was lower due to low nutrient concentration and dry matter content but quantity of added nutrient was high. Moreover, it is important that crops need a trace amount of micro nutrient for optimum growth. The balance was high that might be due to less uptake than that of added amount in the soil. However, from mean data it was noticeable that the crop residue incorporated treatments showed higher positive and lower negative balance than that of none incorporated treatments. That was possibly due to the addition of extra nutrient from crop residues in the range of 0.02 to $0.06 \mathrm{~kg}$ ha ${ }^{1} \mathrm{yr}^{-1}$ (Table 3). Similar results were reported by Bhuiyan (2004) in wheat-T. Aus/Mungbean-T. Aman rice cropping pattern and Basak et al. (2008) in Groundnut-T. Aus-T. Aman rice cropping pattern.

\section{Boron}

The range of added boron was $0-1.20 \mathrm{~kg} \mathrm{ha}^{-1} \mathrm{yr}^{-1}$ and uptake ranged from 0.04 to $0.20 \mathrm{~kg} \mathrm{ha}^{-1} \mathrm{yr}^{-1}$. The uptake was the highest in a number of treatments $(0.20 \mathrm{~kg}$ $\left.\mathrm{ha}^{-1}\right)$. The CON and CON+CRI $\left(0.04 \mathrm{~kg} \mathrm{ha}^{-1} \mathrm{yr}^{-1}\right)$ had the lowest uptake. The minimum negative balance was found in CON+CRI $\left(-0.04 \mathrm{~kg} \mathrm{ha}^{-1} \mathrm{yr}^{-1}\right)$ and the maximum negative balance was in FP $\left(-0.11 \mathrm{~kg} \mathrm{ha}^{-1} \mathrm{yr}^{-1}\right)$ (Fig. 6). Other treatments showed positive balance ranged from 0.72 to $1.00 \mathrm{~kg} \mathrm{ha}^{-1}$. The highest positive balance was found in HYG and HYG+CRI $\left(1.00 \mathrm{~kg} \mathrm{ha}^{-1} \mathrm{yr}^{-1}\right)$. The lowest positive balance was observed in MYG and MYG+CRI $\left(0.72 \mathrm{~kg} \mathrm{ha}^{-1} \mathrm{yr}^{-1}\right)$.

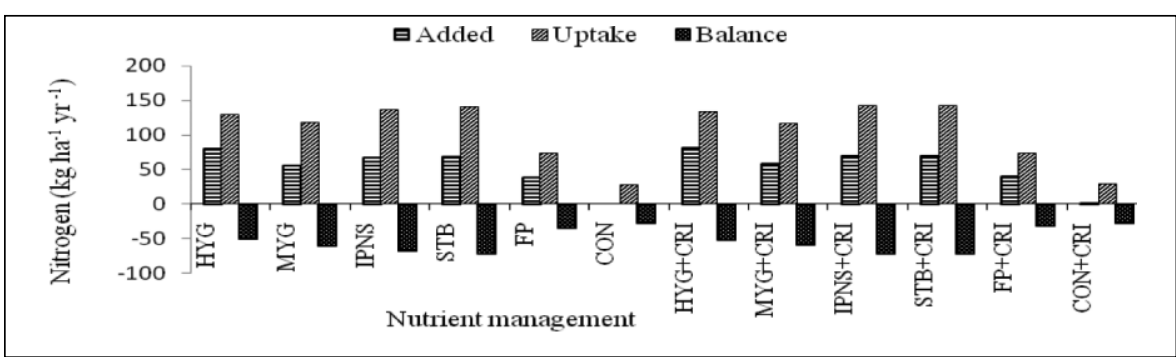

Fig. 1. Apparent $\mathrm{N}$ balance of potato as influenced by different nutrient management (mean of two years)

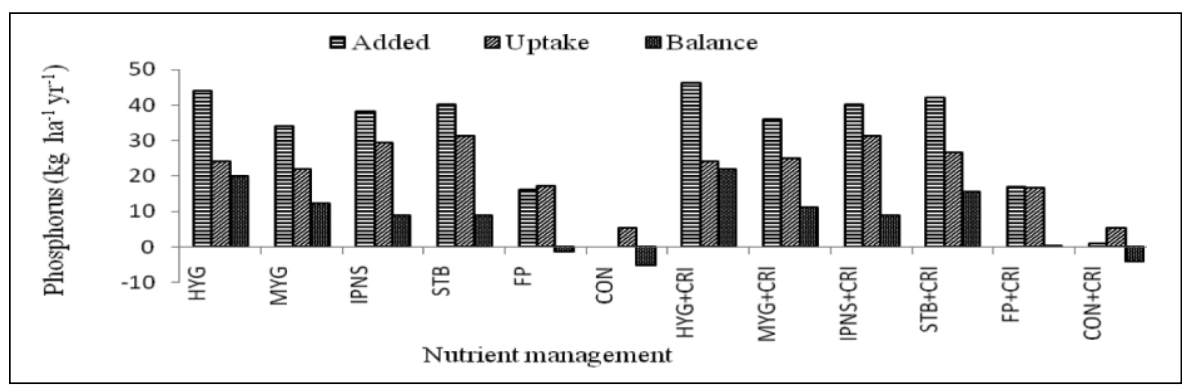

Fig. 2. Apparent $P$ balance of potato as influenced by different nutrient management (mean of years) 
From the above results, it was observed that only two treatments i.e. FP and control showed negative balance possibly due to lack of optimum nutrient and no addition of nutrient (native nutrient only) in the soil. Although some amount of nutrient was removed by the plants for total dry matter production and variation of nutrient concentration. Remaining treatments showed positive balance which might be due to addition of higher amount of nutrient from different sources. Moreover, it is important that a crop requires a trace amount of micro nutrient for proper crop growth. However, the positive balance was higher and negative balance was lower in those treatments where crop residues were incorporated into soil, which might be due to addition of extra nutrient from crop residue incorporation. The range of additional nutrient applied was 0.01 to $0.03 \mathrm{~kg} \mathrm{ha}^{-1} \mathrm{yr}^{-}$ ${ }^{1}$ (Table 3). Similar results were reported by Bhuiyan (2004) in Wheat-T. Aus/ Mungbean- T. Aman rice cropping pattern.

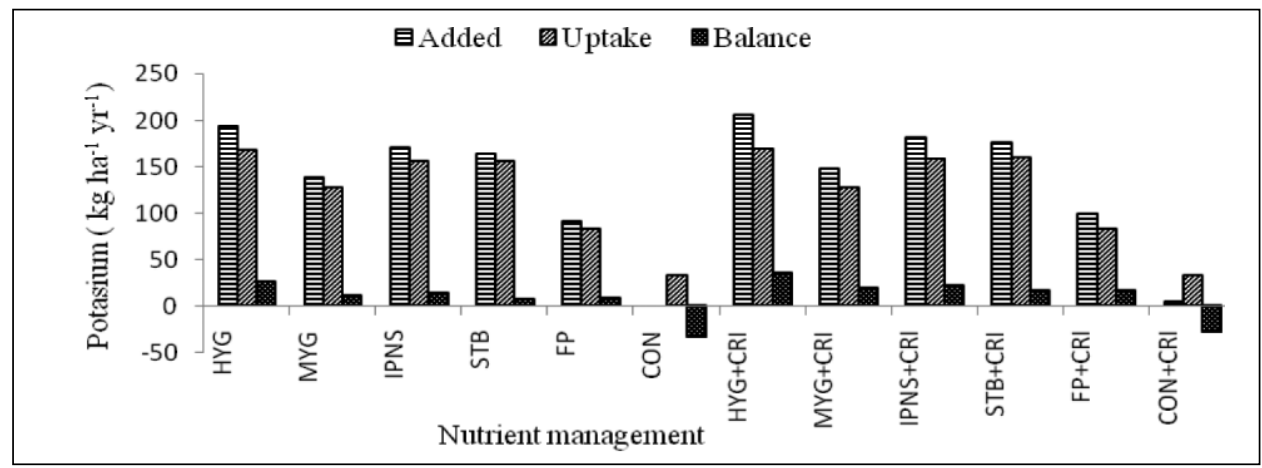

Fig. 3. Apparent $\mathrm{K}$ balance of potato as influenced by different nutrient management (mean of years)

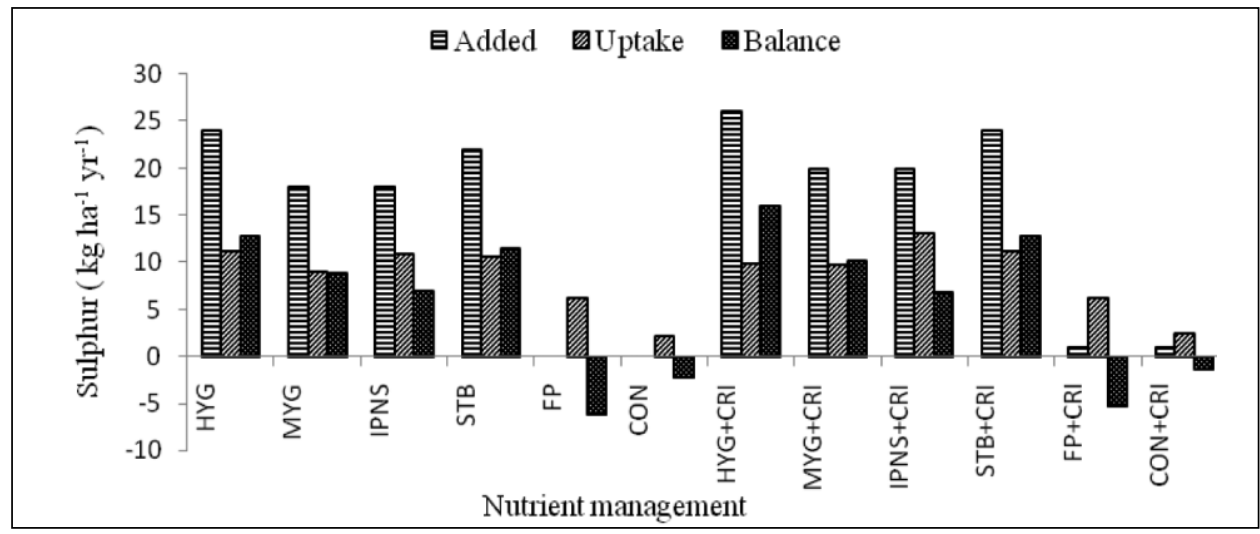

Fig. 4. Apparent $S$ balance of potato as influenced by different nutrient management (mean of two years) 


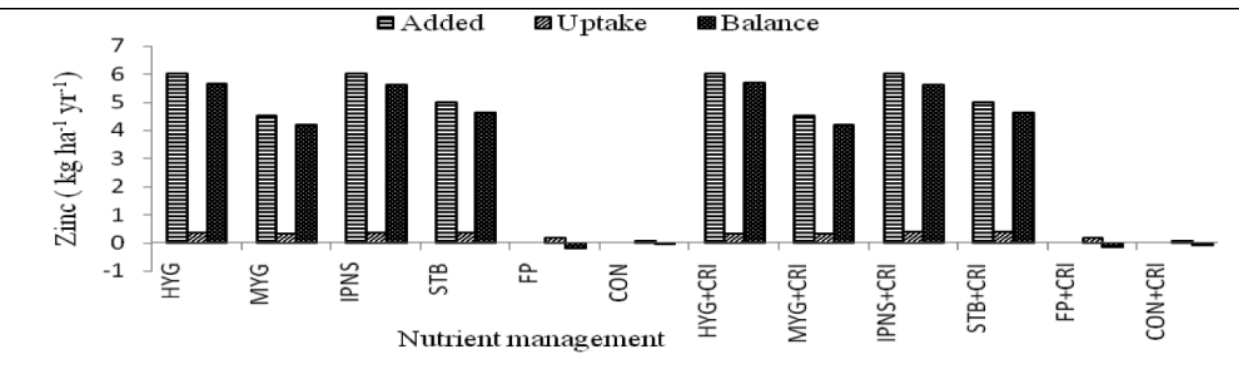

Fig. 5. Apparent $\mathrm{Zn}$ balance of potato as influenced by different nutrient management (mean of two years)

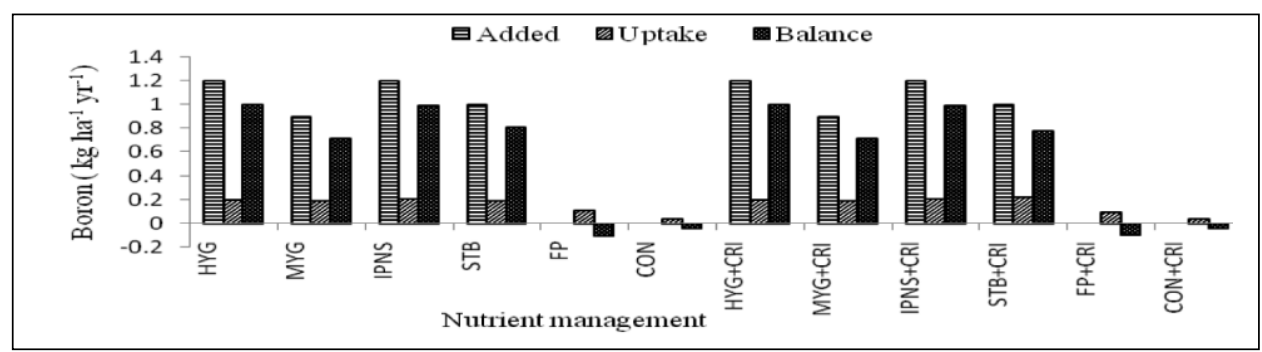

Fig. 6. Apparent B balance of potato as influenced by different nutrient management (mean of two years)

On an average of two years, major plant nutrients like $\mathrm{N}\left(1.71\right.$ to $5.67 \mathrm{~kg} \mathrm{ha}^{-1}$ $\left.\mathrm{yr}^{-1}\right), \mathrm{P}\left(0.86\right.$ to $\left.2.67 \mathrm{~kg} \mathrm{ha}^{-1} \mathrm{yr}^{-1}\right)$, ) $\mathrm{K}\left(5.00\right.$ to $\left.12.92 \mathrm{~kg} \mathrm{ha}^{-1} \mathrm{yr}^{-1}\right), \mathrm{S}(0.83$ to 2.31 $\left.\mathrm{kg} \mathrm{ha}^{-1} \mathrm{yr}^{-1}\right)$ and minor nutrients like $\mathrm{Zn}\left(0.02\right.$ to $\left.0.06 \mathrm{~kg} \mathrm{ha}^{-1} \mathrm{yr}^{-1}\right)$ and $\mathrm{B}(0.01$ to $0.04 \mathrm{~kg} \mathrm{ha}^{-1} \mathrm{yr}^{-1}$ ) were added into the soil through crop residues incorporation. The amount was varied depend on irrespective treatment as well as the crop growth. That was an approach for conservation agriculture which might have played a vital role for sustaining soil health like fertility and productivity. This approach might be helpful for a long run.

Table 3. Total addition of extra nutrients into the soil through crop residues incorporation in potato $\left(\mathrm{kg} \mathrm{ha}^{-1} \mathrm{yr}^{-1}\right)$ during 2006-07 and 2007-2008 (Assuming nitrogen mineralization rate 40\%).

\begin{tabular}{l|c|c|c|c|c|c|c|c|c|c|c|c}
\hline \multirow{2}{*}{$\begin{array}{c}\text { Nutrient } \\
\text { management }\end{array}$} & \multicolumn{6}{|c|}{ 2006-2007 $\left(\mathrm{kg} \mathrm{ha}^{-1} \mathrm{yr}^{-1}\right)$} & \multicolumn{5}{c}{ 2007-2008 $\left(\mathrm{kg} \mathrm{ha}^{-1} \mathrm{yr}^{-1}\right)$} \\
\cline { 2 - 13 } & $\mathrm{N}$ & $\mathrm{P}$ & \multicolumn{1}{c}{$\mathrm{K}$} & $\mathrm{S}$ & $\mathrm{Zn}$ & $\mathrm{B}$ & $\mathrm{N}$ & $\mathrm{P}$ & $\mathrm{K}$ & $\mathrm{S}$ & $\mathrm{Zn}$ & $\mathrm{B}$ \\
\hline HYG+CRI & 4.25 & 2.01 & 10.52 & 1.80 & 0.05 & 0.03 & 5.49 & 2.34 & 11.84 & 1.92 & 0.06 & 0.03 \\
MYG+CRI & 3.58 & 1.78 & 8.91 & 1.64 & 0.05 & 0.03 & 4.38 & 2.06 & 10.01 & 1.85 & 0.05 & 0.03 \\
IPNS+CRI & 4.06 & 2.17 & 10.47 & 1.77 & 0.05 & 0.03 & 5.67 & 2.65 & 12.45 & 2.00 & 0.06 & 0.04 \\
STB+CRI & 4.05 & 2.30 & 10.97 & 1.99 & 0.05 & 0.03 & 5.28 & 2.67 & 12.92 & 2.31 & 0.06 & 0.04 \\
FP+CRI & 2.81 & 1.46 & 7.45 & 1.35 & 0.03 & 0.02 & 2.79 & 1.52 & 7.58 & 1.38 & 0.03 & 0.02 \\
CON+CRI & 1.71 & 0.88 & 5.00 & 0.83 & 0.02 & 0.01 & 1.83 & 0.86 & 5.41 & 0.84 & 0.02 & 0.01 \\
\hline
\end{tabular}




\section{Economic assessment of potato cultivation as influenced by different nutrient managements}

Potato production was evaluated through different nutrient management treatments and results are furnished in Table 4. Average of two years results revealed that STB+CRI nutrient management gave the highest gross return (Tk. $283331 \mathrm{ha}^{-1}$ ) followed by IPNS+CRI (Tk. $280421 \mathrm{ha}^{-1}$ ), STB (Tk. $280419 \mathrm{ha}^{-1}$ ), and IPNS (Tk. 277664 ha $^{-1}$ ) nutrient management treatments due to higher yield.

Table 4 further revealed that STB+CRI nutrient management produced the highest net return (Tk. $211761 \mathrm{ha}^{-1}$ ) followed by STB (Tk. $209086 \mathrm{ha}^{-1}$ ), IPNS+CRI (Tk. 205874 ha $^{-1}$ ) and IPNS (Tk. 203353 ha $^{-1}$ ) due to irrespective total costs.

Table 4. Economic performance of potato influenced by different nutrient management treatments at Gazipur (mean of 2006-07 and 2007-08).

\begin{tabular}{l|c|c|c|c}
\hline \multirow{2}{*}{$\begin{array}{c}\text { Nutrient } \\
\text { management }\end{array}$} & $\begin{array}{c}\text { Total cost } \\
\text { (Taka }\end{array}$ & $\begin{array}{c}\text { Gross return } \\
\text { (Taka }\end{array}$ & $\begin{array}{c}\text { Net return } \\
\text { (Taka) }\end{array}$ & BCR \\
\cline { 2 - 5 } & 1 & 2 & $3=(2-1)$ & $4=(2 / 1)$ \\
\hline HYG & 72986 & 265857 & 192871 & 3.64 \\
MYG & 68922 & 229936 & 161014 & 3.34 \\
IPNS & 74311 & 277664 & 203353 & 3.74 \\
STB & 71333 & 280419 & 209086 & 3.93 \\
FP & 63506 & 151748 & 88242 & 2.39 \\
CON & 57723 & 60886 & 3163 & 1.06 \\
HYG+CRI & 73202 & 267211 & 194009 & 3.65 \\
MYG+CRI & 69111 & 231140 & 162029 & 3.35 \\
IPNS+CRI & 74547 & 280421 & 205874 & 3.76 \\
STB+CRI & 71570 & 283331 & 211761 & 3.96 \\
FP+CRI & 63583 & 152473 & 88890 & 2.40 \\
CON+CRI & 57758 & 61237 & 3479 & 1.06 \\
\hline
\end{tabular}

Here, HYG=0-198-44-194-24-6-1.2, MYG=0-140-34-138-18-4.5-0.9, IPNS=10-168-38170-18-6-1.2, STB=0-171-40-164-22-5-1, FP=0-97-16-91-0-0-0, CON=0-0-0-0-0-0-0, $\mathrm{CD}\left(\mathrm{t} \mathrm{ha}{ }^{-1}\right), \mathrm{N}, \mathrm{P}, \mathrm{K}, \mathrm{S}, \mathrm{Zn}, \mathrm{B}\left(\mathrm{kg} \mathrm{ha}^{-1}\right)$, respectively and $\mathrm{CRI}=$ Crop Residue Incorporation.

Input and output prices (Anon. 2007): Urea-6.50 (Tk. $\mathrm{kg}^{-1}$ ), TSP-19.00, MP-15.00, Gypsum-4.60, Zincsulphate-65.00, Boric acid-100, Cowdung-0.32 and Crop reside- 0.10 (dry basis)

Potato tuber-10 ((Tk. $\left.\mathrm{kg}^{-1}\right)$ and Potato foliage- 0.10 (dry basis) 
In STB+CRI nutrient management, though the cost of crop residue was considered in the calculation that resulted in higher total cost. Due to higher yield obtained in STB+CRI nutrient management was higher profitable (BCR 3.96) followed by STB (BCR 3.93), IPNS+CRI (BCR 3.76), and IPNS (BCR 3.74).

The overall economic performance of the aforesaid result showed that potato was sustainable, feasible considering applied STB+CRI nutrient management. The other best alternative nutrient managements were STB, IPNS+CRI, and IPNS. Nevertheless, STB+CRI nutrient management also gave higher net return compared to other nutrient managements. Many scientists (Ali et al., $2009 \mathrm{a} \& \mathrm{~b}$; Biswas et al., 2004, 2007, 2008; Zaman et al., 2007 a \& b) conducted similar type of experiments with different cropping patterns without crop residue incorporation into the soil and found more or less similar results.

However, STB along with and without crop residue incorporation might be suitable for potato production as well in economic point of view but IPNS may be used for sustaining soil health as well yield and benefit.

\section{Conclusion}

Soil test based (171-40-164-22-5-1 N P K S Zn B kg ha-1) along with or without crop residue incorporation could be suitable for getting higher tuber yield and economic benefit of potato cultivation but maintaining sustainable good soil health IPNS (10-168-38-17018-6-1.2 CD, N P K S Zn B t ha-1) could be used for long term basis.

\section{References}

Ali, M.R., D.J. Costa, M.A. Sayed, M.A.H. Khan and J.A. Abedin. 2009. Development of fertilizer recommendation for the cropping pattern Potato-Boro-T. Aman in irrigated medium high land condition under AEZ-9. Bangladesh J. Agril. Res. 34(1):41-49.

Anonymous. 2007. Annual report, Agricultural Economics Division, BARI, Joydebpur, Gazipur, Bangladesh. Pp. 33-93.

BARC (Bangladesh Agricultural Research Council). 2005. Fertilizer Recommendation Guide-2005. Bangladesh Agril. Res. Council, New Airport Road, Farmgate, Dhaka.

Basak, N.C., M.A. Quayyum, S.M. Asaduzzaman, N. Sultana and M.A.H. Khan.2008. Integrated nutrient management in the Mustard-Boro rice-T. Aman rice cropping system. Bangladesh J. Agril. Res. 33(1): 135-143.

BBS (Bangladesh Bureau of Statistics). 2011. Statistical Year Book of Bangladesh. Bangladesh Bur. Stat., Stat. Div., Minis. Plan., Govt. People's Repub. Bangladesh. Dhaka, Bangladesh. pp. 27-29. 
Bhuiyan, M.A.H. 2004. Evaluation of introducing mungbean into cereal based cropping pattern for sustainable soil fertility and productivity. Ph D Thesis. Dept. of Soil Science, Bangladesh Agricultural University, Mymensingh.

Biswas, J.C., M. Maniruzzaman, M.A. Sattar and M.G. Neogi. 2008. Improvement of existing rice yield through recommended fertilizer and cultural management at farmers' fields. Bangladesh Rice J. 13 (1): 9-14.

Biswas, J.C., M.R. Islam and M.J. Islam. 2007. Crop Productivity as influenced by soil test based fertilizer management in six cropping patterns at farmers' field. SAARC J. of Agri. 5(1): 33-42.

Biswas, J. C., M. R. Islam, S. R. Biswas and M. J. Islam. 2004. Crop productivity at farmers field options for soil test based fertilizer use and cropping pattern s. Bangladesh Agron. J. 10(1\&2): 31-41.

Biswas, S.K. 2011. Effect of irrigation with municipal waste water on wheat and potato cultivation. Ph D Dissertation. Department of Irrigation and Water management. Bangladesh Agricultural University, Mymensingh, Bangladesh. Pp. 217.

Chowdhury, D.A, M.K. Hasan, A.A. Mahmud, M.R. Amin and M.A.H. Khan. 2007. Effect of different fertilizer doses on the agro-economic productivity of potatojute cropping pattern in medium low land ecology at Munshiganj. Intl. J. BioRes. 3(5):13-19.

Couto, F. A. A., L. C. Sikka and S. P. R. Weerasinghe. 1983. The potato in the lower tropics.In : W. J. Hooker (ed.) " Research for the potato in the year 2000". International potato centre (CIP),

Hossain, M.F., M.A. Salam, M.S. Hossain, M. Badirul Islam and M.S. Islam. 2008. Nutrient management for Potato-Fallow-T. Aman rice cropping pattern at high Barind tract. Int. J. Sustain. Agril. Tech. 4(3): 86-91.

Khan, M.A.H., M.A. Quayyum, D.A. Choudhury, M.I. Nazrul and M.R. Ali. 2005. Integrated nutrient management for Potato-T. Aus-T. Aman rice cropping system. Bangladesh Agron. J. 11(1 \& 2): 89-96.

Panaullah, G.M., M.A. Saleque, J. Timsina, M. Ishaque, A.B.M.B.U. Pathan, M.A. Quayyum, D.J. Connor, P.K. Saha, E. Humphreys and C.A. Meisner. 2006. Nutrient uptake and apparent balances for Rice-Wheat sequences. III. Potassium. Journal of Plant Nutrition. 29: 173-187.

Saleque, M.A., J., Timsina, G.M. Panaulah, M. Ishaque, A.B.M.B.U. Pathan, M.A. Quayyum, D.J. Connor, P.K. Saha, E. Humphreys and C.A. Meisner. 2006. Nutrient uptake and apparent balances for Rice-Wheat sequences. II. Phosphorus. Journal of Plant Nutrition. 28: 157-172.

Sarkar, N.I., S. Zaman, M.S. Islam, M. Badirul Islam and M.A. Mannaf. 1996. Effect of fertilizers alone and in combination with cowdung on the growth and yield of potato. Bangladesh J. Agril. Res. 21(2): 275-282.

Satter, M. A., M. A. Rahman, H.U. Rashid, M.S. Ali and M.S. Alom. 2005. Krishi Projukti Hatboi (Handbook on Agro-technology), $3^{\text {rd }}$ edition, Bangladesh Agricultural Research Institute, Gazipur-1701, Bangladesh. Pp. 1-559. 
Timsina, J., G.M. Panaulah, M.A. Saleque, M. Ishaque, A.B.M.B.U Pathan, M.A. Quayyum, D.J. Connor, P.K. Saha, E. Humphreys and C.A. Meisner. 2006. Nutrient uptake and apparent balances for Rice-Wheat sequences. I. Nitrogen. Journal of Plant Nutrition. 29: 137-155.

Timsina, J., U. Singh, M. Badaruddin, C.A. Meisner and M.R. Amin. 2001. Cultivar, nitrogen and water effects on productivity and nitrogen-use efficiency and balance for rice-wheat sequences of Bangladesh. Field Crop Research. 72: 143-161.

Woolfe, J.A.1987. The potato of the human diet. Published in collaboration with international potato centre, Cambridge University Press. Cambridge London, New York, New Rochelle, Melbourne. Sydney. Pp. 26-31.

Zaman, S.M., M.R. Amin, M.Y. Ali, M.A. Hossain and Shamima Aktar. 2007 (a). Nutrient management in Boro-T. Aman cropping system under high Ganges river floodplain soil. Bangladesh J. Agron. and Environ. 3(2):55-63.

Zaman, S.M., M.R. Amin, Q. Naher, S. Aktar, M.K. Uddin and M.S. Rahman. 2007 (b). Evaluation of different nutrient management packages in Sesame-T. Aman cropping system under Ganges tidal floodplain. Intl. J. BioRes. 2(4):1-5. 